\title{
CLASTERS AND CORRELATIONS AMONG THE EU MEMBER STATES REGARDING AGRI-FOOD FOREIGN TRADE
}

\author{
Nóra Gombkötő \\ Széchenyi István University Faculty of Agricultural and Food Sciences
}

E-mail: gombkoto.nora@sze.hu

\begin{abstract}
The European Union has a significant role in international trade but this is largely in the area of industrial goods. However, in the case of some agricultural commodities the EU applies tariffs, bans, or different restrictive measures; it manages foreign trade in agricultural goods with many countries all over the world. On the other hand the member states do not contribute to the total trade of the EU to the same extent. In this study, a comparative analysis was performed in relation to the member states by means of data of Eurostat and Faostat. First, a multivariable correlation analysis was carried out in order to find the interrelation between the trade features of each country. In the second part of the study, a cluster analysis was carried out with almost the same component as in the foregoing, also in terms of the EU member states. It can be ascertained that the date of EU accession of a Member State as well as getting EU agricultural subsidies do not affect the agricultural foreign trade of the member states. Countries with significant agricultural production also export food commodities in larger quantities. Countries that have significant exports extra-EU also have larger imports in the case of both basic commodities and prepared food as well. As a result of the cluster analysis, it can be stated that the member states can be divided into specific groups according to the three examined aspects (food trade features, exports of commodities, imports of commodities). The following typical country groups can be divided as follows: non-trade countries, countries with larger trade extra-EU, agri-food exporter and importer countries, non-agri-food exporter and importer countries, primary commodity exporters and importers, and last but not least processed food exporters and importers as well.
\end{abstract}

Keywords: agri-food trade, EU member states, correlation matrix, cluster analysis, classification (JEL Classification: F10

\section{INTRODUCTION}

The European Union is one of the most open economies in the world with a number of trading partners. It is the largest trading partner for almost 60 countries (MAZURE and TILTINA 2015) and its aim is to expand trade relations more widely. The EU trading partners benefit from preferential tariff access to the EU given that the EU has entered into free trade agreements with more than 30 countries. Approximately $46 \%$ of extra-EU trade is directed towards developed countries. (According to BRÜLHART and MATTHEWS (2007), if intra-EU trade is added to extra-EU trade with developed countries, then more than four fifths of the EU's trade is with countries of broadly similar income levels.) However, industry contributes to this most significantly because the EU exports of agricultural commodities make up about $8 \%$ of total exports. In the case of both industry and agriculture the main obstacles for further development are the numerous still existing nontariff barriers to trade. The reduction of tariffs on agriculture is the core issue regarding market access, while preserving special treatment for the EU's traditional sensitive products (EPP, 2015). According to the World Trade Organization (WTO) Statistics, the United
States, China, Switzerland, and Russian Federation are the major EU co-partners (mainly importers) in agricultural goods, and the United States and China are the EU's key strategic commercial partners. The European Union and the United States jointly represent more than $30 \%$ of global trade. Although China is second only to the US, the volume of trade in goods with China has greatly increased in recent years (EPP, 2015).

In the EU, there is a single market for the member states, which works as a unique global market. There are set uniform rules under the Customs Union and the Common Customs Tariff and it governs trade relations of the member states with the nonmember states. As a result, rates in international movement of goods are clearly decreasing (MAZURE and TILTINA 2015).

The establishment of the single market and tariff reduction have clearly had a positive impact on the EU's trade performance, which is the basis for its growth. EICHER AND HENN (2011) have supported this with concrete data in that the value of goods exchanged between EU countries has grown from 800 million EUR in 1992 to 2.8 trillion EUR in 2011, for trade between the EU and the rest of the world - from 500 billion EUR in 1992 to 1.5 trillion EUR in 2011 (MAZURE and TILTINA 2015). 
Figure 1: Agricultural trade value of the EU member states in 2017 (Million USD)

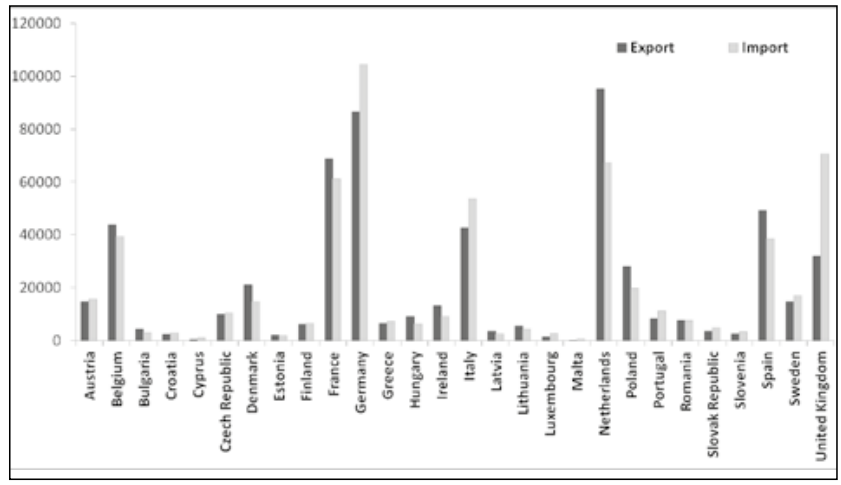

Source: own based on data of WTO statistics

However, EU member states do not contribute to the total trade of the EU to the same extent (figure 1). In the EU, there are main agri-food exporter and importer countries, which position is relatively permanent. Based on the data of Eurostat, it can be found that during the period from 2000 to 2017 , the five major agri-food exporter and importer countries have not changed their positions.

Germany is the European leader in international agrifood trade both in exports and imports and it is followed by Netherlands, Belgium, France, Italy, Spain, and the United Kingdom. In 2017, Germany retained the leading position in the field of foreign trade with exported farm products, amounting to $15 \%$ of agricultural goods that were exported to the third countries and imported these types of goods, which accounted for almost one-fifth (18\%) of the EU-28 member states import volume. Furthermore, Germany is the fourth largest exporter and importer in the world (including the EU). (Although
Netherlands' export share is somewhat higher (16\%) than Germany's, it is due to the fact that Netherlands is a major re-exporter.)

As for the type of farm products involved in trade in the EU, there are main export and import goods but there are some type of commodities that are traded. Within the total agricultural exports, alcohol, wine, wheat, and malt extract are at the top of the list of farm exports by value (as of 10 January 2017, listed on the WTO's website).

Export and import quantities of some commodity categories by EU member states are indicated in table 1. The 2-5 largest values of commodities are shaded in grey. In almost all cases the same countries have roles in both exports and imports.

Food commodities are more important export and import products than other agricultural raw commodities. From that wine, cereals, fruits, vegetables, dairy products, and meat preparations are exported, while oilseeds, fruits, and vegetables are imported in larger quantities. As for dairy products, for European dairy farmers most of the gains are for

Table 1: Trade of agricultural commodities by EU member states in 2017 (thousand tonnes)

\begin{tabular}{|c|c|c|c|c|c|c|c|c|c|c|}
\hline \multirow[b]{2}{*}{ Member state } & \multicolumn{5}{|c|}{ Exports } & \multicolumn{5}{|c|}{ Imports } \\
\hline & Cereals & Oilseeds & Sugar & $\begin{array}{l}\text { Fresh } \\
\text { milk }\end{array}$ & \begin{tabular}{|c|} 
Wine + \\
vermouth
\end{tabular} & Cereals & Oilseeds & Sugar & $\begin{array}{l}\text { Fresh } \\
\text { milk }\end{array}$ & $\begin{array}{c}\text { Wine+ } \\
\text { vermouth }\end{array}$ \\
\hline Austria & 1194 & 1948 & 211 & 528 & 251 & 315 & 810 & 75 & 48 & 84 \\
\hline Bulgaria & 6300 & 119 & 1601 & 46 & 188 & 285 & 7 & 24 & 54 & 7 \\
\hline Cyprus & 16 & 463 & 0 & 4 & 0 & 20 & 1 & 9 & 1 & 7 \\
\hline Denmark & 1578 & 879 & 161 & 130 & 308 & 370 & 256 & 61 & 48 & 206 \\
\hline Estonia & 486 & 144 & 62 & 24 & 22 & 59 & 213 & 16 & 4 & 24 \\
\hline Finland & 641 & 114 & 1 & 182 & 44 & 262 & 26 & 55 & 2 & 65 \\
\hline France & 33625 & 1837 & 1795 & 2210 & 2022 & 1286 & 1147 & 819 & 1533 & 569 \\
\hline Germany & 13732 & 8778 & 233 & 9096 & 1912 & 1942 & 2355 & 1775 & 434 & 1541 \\
\hline Greece & 414 & 1424 & 236 & 404 & 70 & 409 & 2 & 158 & 27 & 19 \\
\hline Hungary & 5342 & 341 & 835 & 457 & 550 & 366 & 394 & 97 & 53 & 47 \\
\hline Croatia & 559 & 113 & 160 & 13 & 125 & 150 & 18 & 151 & 3 & 13 \\
\hline Ireland & 114 & 1489 & 18 & 61 & 49 & 458 & 226 & 329 & 1 & 77 \\
\hline Italy & 1261 & 10841 & 188 & 1932 & 401 & 1939 & 41 & 2269 & 2163 & 270 \\
\hline Latvia & 1353 & 372 & 238 & 82 & 41 & 129 & 263 & 75 & 46 & 51 \\
\hline Lithuania & 2524 & 326 & 374 & 29 & 163 & 98 & 161 & 421 & 83 & 117 \\
\hline Malta & 1 & 133 & 0 & 1 & 0 & 33 & 0 & 5 & 0 & 5 \\
\hline Nether-lands & 1616 & 10864 & 2636 & 6100 & 1147 & 1064 & 543 & 824 & 34 & 379 \\
\hline $\begin{array}{l}\text { Czech } \\
\text { Republic }\end{array}$ & 2238 & 376 & 594 & 262 & 385 & 313 & 716 & 95 & 30 & 143 \\
\hline Poland & 4079 & 1293 & 771 & 425 & 826 & 556 & 343 & 216 & 5 & 112 \\
\hline Portugal & 139 & 3236 & 89 & 1303 & 240 & 633 & 229 & 163 & 307 & 163 \\
\hline Romania & 9219 & 1402 & 1939 & 254 & 135 & 511 & 28 & 139 & 11 & 38 \\
\hline Slovenia & 272 & 522 & 73 & 65 & 67 & 131 & 280 & 75 & 8 & 9 \\
\hline Slovakia & 1090 & 257 & 693 & 52 & 467 & 221 & 250 & 120 & 16 & 56 \\
\hline Spain & 1440 & 9904 & 115 & 3949 & 316 & 1675 & 201 & 445 & 1938 & 166 \\
\hline Sweden & 856 & 483 & 52 & 199 & 130 & 194 & 73 & 44 & 8 & 207 \\
\hline $\begin{array}{l}\text { United } \\
\text { Kingdom }\end{array}$ & 1912 & 6134 & 476 & 1021 & 395 & 2648 & 550 & 245 & 101 & 1286 \\
\hline Belgium & 2258 & 7853 & 1042 & 2958 & 1030 & 1774 & 1045 & 1039 & 32 & 334 \\
\hline Luxem-bourg & 105 & 140 & 14 & 10 & 1 & 11 & 164 & 30 & 5 & 22 \\
\hline
\end{tabular}

Source: own based on data of Faostat 
cheese, while other dairy products are not so important. Even despite increasing trade dairy prices are falling constantly, and in some member states (Austria, Benelux) the value of the entire dairy industry is predicted to decline. (BECKMAN, 2015; BUREAU, 2014)

Although, the US and EU are both major producers, their most important crops differ from each other (IGC, 2016). Consequently, trade in crops is minor between the two regions. The US is not an important destination for any EU cereals or oilseeds, and the only major US export to the EU is of soybeans and soymeal (DG AGRICULTURE AND RURAL DEVELOPMENT, 2015).

There is also a very little trade in poultry products and eggs between the US and EU because welfare standards are generally weaker in the US; there is mostly only voluntary regulations for animal welfare, while poultry farmers in the EU must conform to stricter legislative requirements. Although, US's pork production has stricter animal welfare standards, the EU does not allow the marketing of meat containing residues of growth promoters, such as ractopamine, due to concerns about its safety for consumers. As such US beef imports are restricted due to the EU's ban on beef hormones and limited import quota for hormone-free beef.

90\% of GI exports outside the EU are of wines and spirits, domestic and EU markets are far more important for producers of GI foodstuffs. In fact, just three member states (France, Italy and the UK) accounted for $86 \%$ of GI exports in 2010, with a very small number of products accounting for much of this trade (CHEVER et al. 2012).

\section{MATERIALS AND METHODS}

Taking into account each EU member state's numerical data related to foreign agricultural trade, a multivariable correlation analysis (with correlation matrix) and a cluster analysis were carried out. The aim of the correlation analysis was to determine whether there is any correlation between the foreign trade level of EU member states (with third countries) and other economic factors, such as components of national accounts, agricultural production and subsidies as well as export and import totals and also by product groups. (A further aim was to confirm or reject the statement of the USA according to which the EU's subsidization and anti-liberalization policy in agricultural production are the greatest obstacles to a fully-opened agricultural world trade.) The cluster analysis was carried out in order to ascertain whether the EU member states could be divided into groups according to their trading features. The question is: whether homogeneous or similar country groups or regions may be separated according to the variables? So the aim of the analysis was to categorize the similar member states according to their foreign trade. In both cases data was provided by Eurostat and Faostat for the year of 2017.

In the correlation matrix the cases were the EU member states, while variables were the above-mentioned economic and foreign trade features of each member state. A total of 34 variables were examined and from these variables the main ones were as follows:
- GDP and its main components (GDP, domestic demand, gross value added, share of agricultural gross value added in total gross value added)

- Agricultural production and subsidies (crop production and subsidies, animal production and subsidies)

- Food trade features (export and import values, trade balance, share of exports and imports by partner in total trade, share of exports and imports by product type)

- Export and import value by product groups (cereals, oilseeds, fruit and vegetables, meat, fresh milk, dairy products, prepared food, and sugar)

- Years since becoming a member state

In the cluster analysis the cases were the EU member states, while variables were the foreign trade features of each Member State. The cluster analysis was carried out for each of the food trade features, each of the exports of commodities, each of the imports of commodities. So EU member states were categorized in three ways. In the case of food trade features, a total of 7 variables were examined. These variables were export and import values, trade balance, share of exports and imports by partner in total trade, share of exports and imports by product type. The other two classifications of member states were carried out based on the export and import value and the export and import quantity by product groups. In these two cases a total of 16 variables per model were recorded (cereals, oilseeds, fruit and vegetables, meat, fresh milk, dairy products, prepared food, and sugar). In all three analyses the cases were represented by EU member states. The calculation was carried out by the 'Statistica 13.2 Dell ${ }^{\circ}$ ' computer program based on a tree clustering with complete linkage and with Euclidean distances. This method is in a preference with small diameters over long, straggly clusters, because in this case the similarity of two clusters is the similarity of their most dissimilar members. This is equivalent to choosing the cluster pair whose merge has the smallest diameter. Complete linkage tends to find compact clusters of approximately equal diameters.

The graph of the amalgamation schedule was used to establish the optimal cut-off for the tree diagram. (This graph shows the linkage distances at successive clustering steps.) This diagram was made in all three analyses (figure 2).

Figure 2: Linkage distances across steps

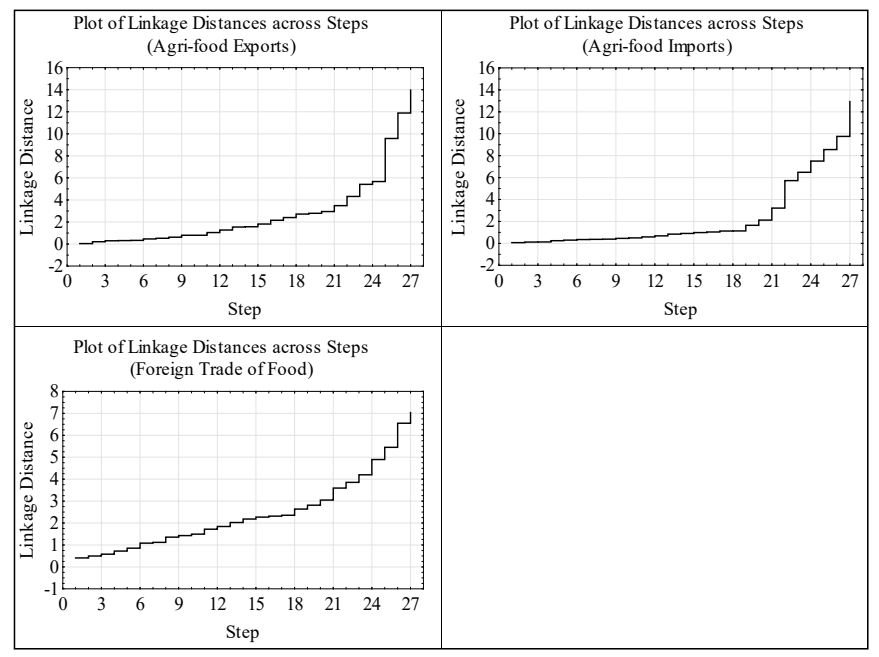


Table 2: Correlaton Matrix of economic and foreign trade features of the EU member states (0.05 significance level)

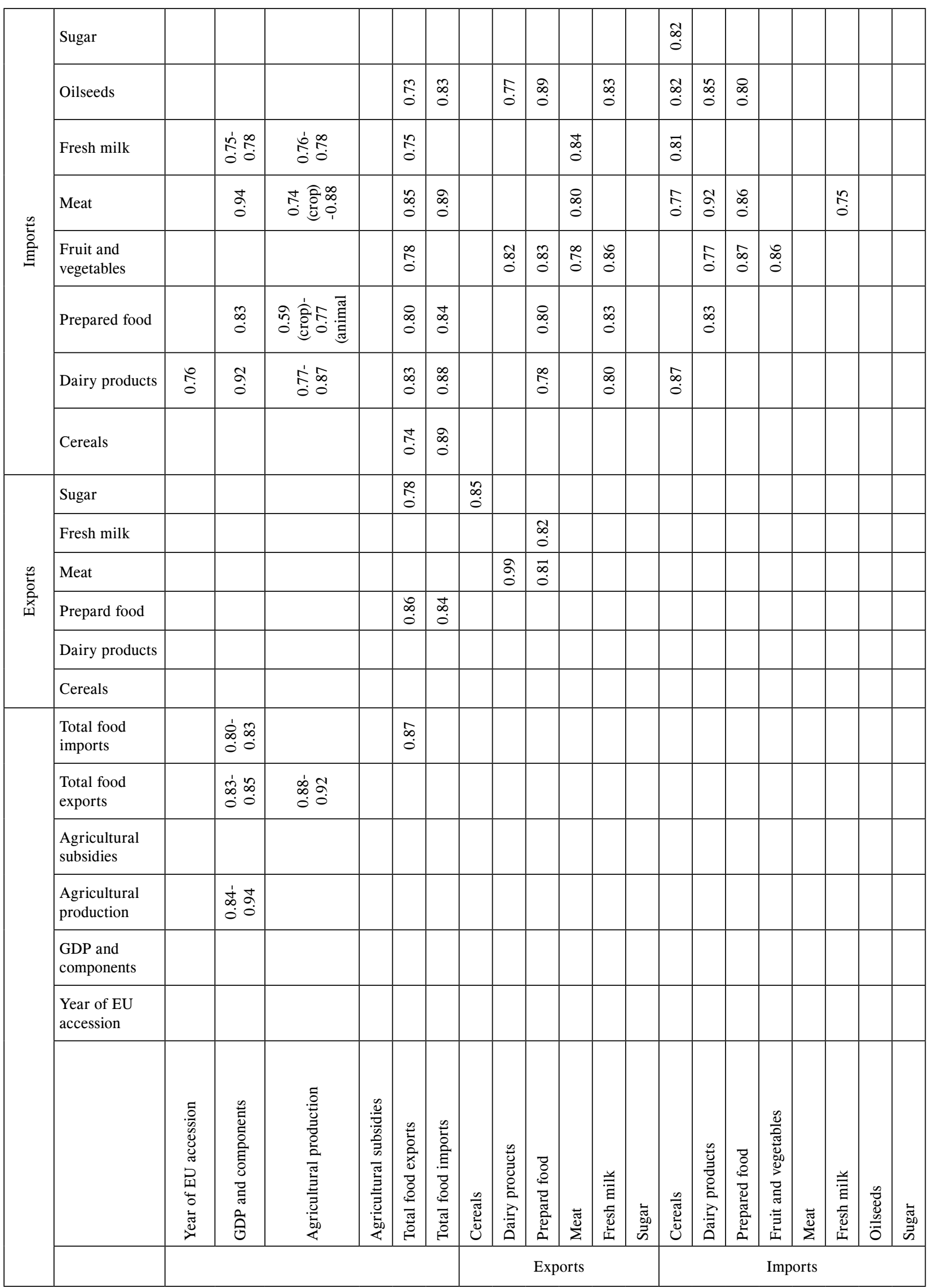


According to these, it needs approximately 18-21 steps to form many clusters at essentially the same linkage distance. In this case the optimal cut-off distance is approximately 1.5 - 2.5 (it varies in each analysis).

Based on the calculated optimal cut-off distances, different country groups were formed in all three analyses. After that, standard deviation and coefficient of variation were calculated within each group and with each variable in order to establish the variable of data in a group. Based on this calculation it can be proved that data within a group are relatively homogenous or their dispersion are medium in most cases, that is the Coefficient of Variation (CV) is less than 20\% (CV shows the extent of variability in relation to the mean of the variables) so these data are adequate to characterize the set country group.

\section{RESULTS AND DISCUSSION}

In table 2 , there is a part of the complete correlation matrix (at significance level of 0.05). Since it is a matrix in which rows and columns contain the same elements, the same result can be seen above the diagonal. Therefore, in this matrix only the numbers located above the diagonal are displayed. Those variables are indicated in the table lie between being strong $(r>0.75)$ and function-like $(r>0.9)$ correlations. Only those values are given that belong to this kind of relations. Nonetheless, neither the crop subsidies nor the animal subsidies correlated with any of the examined variables. This means that agricultural subsidies do not influence the agricultural foreign trade of the member states, so those have no trade-distorting effects.

Current foreign trade of member states is not affected by the year of EU their accession. The accession date is in a medium-strong $(r=0.76)$ relationship only with the imports of dairy products, but this phenomenon can also be caused by random effects.

The share of exports and imports by partner and by products as well as the export value of sugar, fruit and vegetables are not shown in the table because these elements are not correlated with any of the other factors. The detailed components of the GDP can be treated as one variable because these components correlate with the other variables to the same extent.

There are only positive correlations between the variables this means that the higher the value of a factor in a country, the greater the value of another factor.

GDP and its components have strong positive correlation with agricultural production, and with total food exports and imports (especially with the imports of animal products). Agricultural production is also connected to the same variables. Total food exports and imports are in a strong relation with each other, so the country that exports more, also imports in higher quantities. Both of these two factors strongly correlate with the exports of prepared food and with the imports of almost all types of goods. The exports of cereals and the exports of sugar vary in the same direction and to the same extent. The country that exports more dairy products and fresh milk, also imports cereals and oilseeds in a higher quantity. While meat exporter countries have a higher demand for meat, fresh milk as well as fruits and vegetables. Prepared food exports strongly correlate with exports of meat and fresh milk, in addition to imports of dairy products, prepared food, oilseeds, fruits, and vegetables. While prepared food imports are in a strong correlation with the exports of prepared food and fresh milk, and the imports of dairy products, meat, oilseeds, fruits and vegetables.

Based on the clustering according to the food trade features, member states may be separated into five groups (figure 3, table 3).

Figure 3: Tree diagram for EU-28 (by foreign food trade)
To the first group belong those countries that have a relatively lower share of food imports in total food imports by partner countries and by commodities as well. On the other hand they have a relatively higher share of food exports in total food exports by partner countries and by commodities. So exports of food commodities in these countries are much larger than the amount of imports. These countries can be identified as "exporter countries" of food products. These are Ireland, Finland, Estonia, Lithuania, Poland, Austria, Romania, Bulgaria, and Greece. Furthermore, all of them have a positive trade balance. In Luxembourg, Czech Republic, Slovakia, and Hungary all of the features of food foreign trade are much lower than in other member states. These countries do not have a significant foreign trade in food commodities outside the EU. They trade mainly with other EU member states, so they may be designated as "intra-EU trader countries". Compared with other (non-food) commodities, foods are the most important commercial goods in Latvia, Croatia, Cyprus and Malta because these countries have a relatively higher share of food exports and food imports than that of other commodities. So these are the "food trader countries". A further feature of the two last groups is that they have mostly a trade surplus (except 
Luxembourg and Cyprus). Compared with other member states, the "extra-EU trader countries" (United Kingdom, Netherlands, Germany, Italy, and Spain) have the most significant foreign trade (outside the EU) in food products. In these countries, the export and import value as well as the share of foreign trade by partners in total foreign trade are much higher than in other member states. While Sweden, Denmark, Belgium, Portugal, and Slovenia are the main trade partners of the third countries because they have a relatively higher share of food foreign trade in the total food foreign trade by partner countries. It must be mentioned that all of these countries from the last two groups are coastal countries with many big ports, so this is the reason that they can manage such a high level of foreign trade. Furthermore, that is exactly why they have mostly a negative trade balance (except Denmark and Italy).

Table 3: Division of EU member states by foreign trade of food products

\begin{tabular}{|c|c|c|c|c|}
\hline $\begin{array}{l}\text { Exporter } \\
\text { countries }\end{array}$ & $\begin{array}{l}\text { Intra-EU } \\
\text { trader } \\
\text { countries }\end{array}$ & $\begin{array}{l}\text { Food trader } \\
\text { countries }\end{array}$ & $\begin{array}{l}\text { Extra-EU } \\
\text { trader } \\
\text { countries } \\
\text { (coastal } \\
\text { countries) }\end{array}$ & $\begin{array}{l}\text { Main trade } \\
\text { partner } \\
\text { countries } \\
\text { of the third } \\
\text { countries } \\
\text { (coastal } \\
\text { countries) }\end{array}$ \\
\hline $\begin{array}{l}\text { Ireland } \\
\text { Finland } \\
\text { Estonia } \\
\text { Lithuania } \\
\text { Poland } \\
\text { Austria } \\
\text { Romania } \\
\text { Bulgaria } \\
\text { Greece }\end{array}$ & $\begin{array}{l}\text { Luxembourg } \\
\text { Czech } \\
\text { Republic } \\
\text { Slovakia } \\
\text { Hungary }\end{array}$ & $\begin{array}{l}\text { Latvia } \\
\text { Croatia } \\
\text { Cyprus } \\
\text { Malta }\end{array}$ & $\begin{array}{l}\text { United } \\
\text { Kingdom } \\
\text { Netherlands } \\
\text { Germany } \\
\text { Italy } \\
\text { Spain }\end{array}$ & \begin{tabular}{|l} 
Sweden \\
Denmark \\
Belgium \\
Portugal \\
Slovenia
\end{tabular} \\
\hline $\begin{array}{l}\text { A relatively } \\
\text { lower share } \\
\text { of food im- } \\
\text { ports in total } \\
\text { food imports } \\
\text { by partner } \\
\text { countries } \\
\text { and by com- } \\
\text { modities. } \\
\text { A relatively } \\
\text { higher share } \\
\text { of food ex- } \\
\text { ports in total } \\
\text { food imports } \\
\text { by partner } \\
\text { countries } \\
\text { and by com- } \\
\text { modities. } \\
\text { Positive } \\
\text { trade balance } \\
\text { (surplus) }\end{array}$ & $\begin{array}{l}\text { Not signifi- } \\
\text { cant foreign } \\
\text { trade in } \\
\text { foods (extra- } \\
\text { EU) All } \\
\text { features of } \\
\text { food foreign } \\
\text { trade are } \\
\text { much lower } \\
\text { than in other } \\
\text { member } \\
\text { states. } \\
\text { Mostly posi- } \\
\text { tive trade } \\
\text { balance } \\
\text { (surplus) } \\
\text { (except Lux- } \\
\text { embourg) }\end{array}$ & $\begin{array}{l}\text { A relatively } \\
\text { higher share } \\
\text { of food } \\
\text { exports and } \\
\text { food imports } \\
\text { (in other } \\
\text { commodi- } \\
\text { ties). Mostly } \\
\text { positive } \\
\text { trade balance } \\
\text { (surplus) } \\
\text { (except } \\
\text { Cyprus) }\end{array}$ & $\begin{array}{l}\text { The most } \\
\text { significant } \\
\text { foreign trade } \\
\text { in foods } \\
\text { (extra-EU). } \\
\text { The export } \\
\text { and import } \\
\text { value as well } \\
\text { as share of } \\
\text { foreign trade } \\
\text { by partner } \\
\text { countries in } \\
\text { total foreign } \\
\text { trade are } \\
\text { much higher } \\
\text { than in oth- } \\
\text { er member } \\
\text { states. Most- } \\
\text { ly negative } \\
\text { trade balance } \\
\text { (deficit) (ex- } \\
\text { cept Italy) }\end{array}$ & $\begin{array}{l}\text { A relatively } \\
\text { higher share } \\
\text { of food for- } \\
\text { eign trade in } \\
\text { the total food } \\
\text { foreign trade } \\
\text { by partner } \\
\text { countries. } \\
\text { Mostly nega- } \\
\text { tive trade bal- } \\
\text { ance (deficit) } \\
\text { (except Den- } \\
\text { mark) }\end{array}$ \\
\hline
\end{tabular}

Based on the clustering by the export quantity and value of commodity groups member states may also be separated into five groups (figure 4, table 4).
Figure 4: Tree diagram for EU-28 (by agri-food exports)

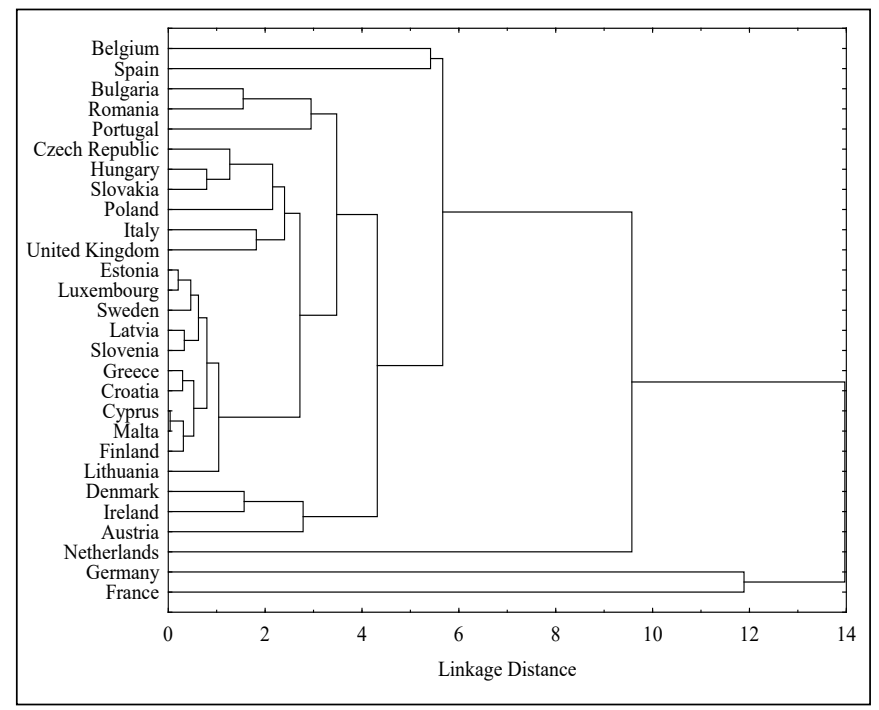

Table 4: Division of EU member states by agri-food exports

\begin{tabular}{|c|c|c|c|c|}
\hline $\begin{array}{c}\text { Non- } \\
\text { agri-food } \\
\text { exporter } \\
\text { countries }\end{array}$ & $\begin{array}{l}\text { Primary } \\
\text { commodity } \\
\text { exporter } \\
\text { countries }\end{array}$ & $\begin{array}{c}\text { Crop } \\
\text { exporter } \\
\text { countries }\end{array}$ & $\begin{array}{l}\text { Processed } \\
\text { food } \\
\text { exporter } \\
\text { countries }\end{array}$ & $\begin{array}{c}\text { Main } \\
\text { agri-food } \\
\text { exporter } \\
\text { countries }\end{array}$ \\
\hline $\begin{array}{c}\text { Finland } \\
\text { Estonia } \\
\text { Latvia } \\
\text { Lithuania } \\
\text { Slovenia } \\
\text { Croatia } \\
\text { Greece } \\
\text { Cyprus } \\
\text { Malta } \\
\text { Luxembourg } \\
\text { Sweden }\end{array}$ & $\begin{array}{l}\text { Poland } \\
\text { Czech } \\
\text { Republic } \\
\text { Slovakia } \\
\text { Hungary }\end{array}$ & $\begin{array}{l}\text { Romania } \\
\text { Bulgaria }\end{array}$ & $\begin{array}{l}\text { United } \\
\text { Kingdom } \\
\text { Italy }\end{array}$ & $\begin{array}{c}\text { Ireland } \\
\text { Denmark } \\
\text { Austria }\end{array}$ \\
\hline $\begin{array}{l}\text { All } \\
\text { commodities } \\
\text { are exported } \\
\text { in the lowest } \\
\text { quantity and } \\
\text { value within } \\
\text { the EU. }\end{array}$ & $\begin{array}{l}\text { Mainly } \\
\text { cereals, } \\
\text { oilseeds, } \\
\text { fresh milk, } \\
\text { fruits and } \\
\text { vegetables } \\
\text { (in some } \\
\text { cases sugar } \\
\text { as well) are } \\
\text { exported. }\end{array}$ & $\begin{array}{l}\text { Cereals and } \\
\text { oilseeds are } \\
\text { exported in } \\
\text { the largest } \\
\text { quantity and } \\
\text { value within } \\
\text { the EU. }\end{array}$ & $\begin{array}{l}\text { Mainly dairy } \\
\text { products (in } \\
\text { the largest } \\
\text { quantity), } \\
\text { meat } \\
\text { and meat } \\
\text { preparations, } \\
\text { processed } \\
\text { food, } \\
\text { fruits and } \\
\text { vegetables } \\
\text { (in the } \\
\text { largest } \\
\text { quantity) are } \\
\text { exported. }\end{array}$ & $\begin{array}{l}\text { Almost all } \\
\text { commodities } \\
\text { are exported } \\
\text { in the largest } \\
\text { quantity and } \\
\text { value within } \\
\text { the EU. }\end{array}$ \\
\hline
\end{tabular}

There are some countries in that exports of agri-food products do not play a significant role. They export mainly non-food goods. These countries are Finland, Estonia, Latvia, Lithuania, Slovenia, Croatia, Greece, Cyprus, Malta, Luxembourg, and Sweden. Poland, Czech, Slovakia and Hungary are similar in that they export mainly primary commodities (such as cereals, oilseeds, fresh milk, fruits, 
and vegetables), while Romania and Bulgaria are typical crop exporter countries (with their largest export quantity and value being cereals and oilseeds). Processed foods are the most important part of the export structure in the United Kingdom and Italy. These countries export mainly meat, meat preparations, and dairy products as well as fruits and vegetables (these two last ones are exported in the largest quantity and value by the UK and Italy from the EU). However, Ireland, Denmark and Austria are the main agri-food exporter countries because the largest quantity of almost all agri-food commodities are exported by these three countries.

Based on the clustering by the import quantity and value of commodity groups member states may be separated into three groups (figure 5, table 5).

Figure 5: Tree diagram for EU-28 (by agri-food imports)

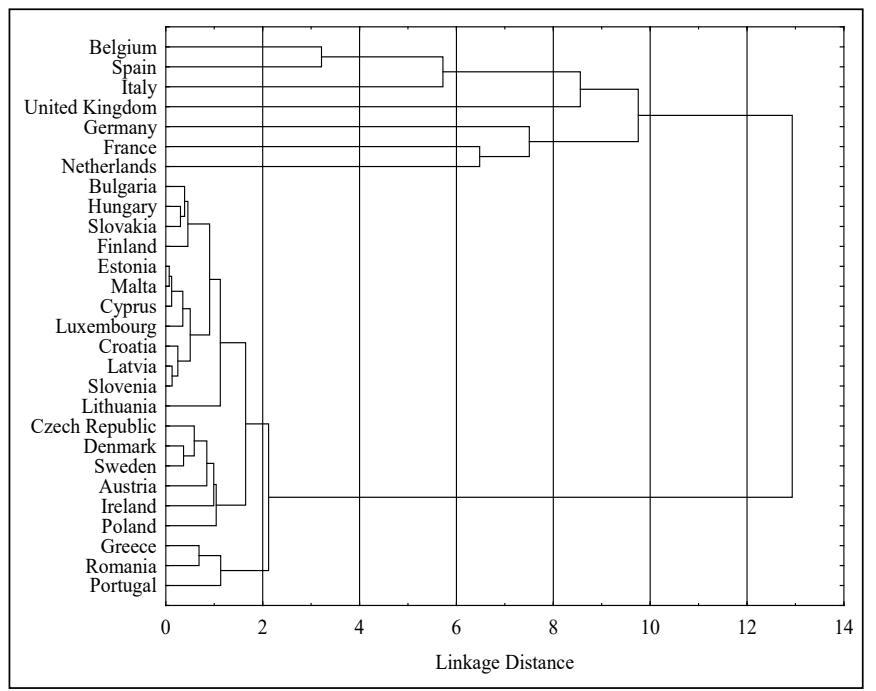

Similar to the export structures, in the case of import structures there are also some countries that the imports of agri-food products do not play a significant role. They import mainly non-food goods. These are Finland, Estonia, Latvia, Lithuania, Slovakia, Hungary, Slovenia, Croatia, Bulgaria, Cyprus, Malta, and Luxembourg. These countries are almost the same countries as the non-agri-food exporter countries. In this classification the processed food importer countries also appear such as Sweden, Denmark, Ireland, Poland, Czech Republic, and Austria. They import dairy products, meat and meat preparations, fresh milk, prepared food, fruits and vegetables in the largest quantity and value within the EU, while primary commodities (such as cereals, fresh milk, and oilseeds) are imported mainly by Portugal, Romania, and Greece.

Table 5: Division of EU member states by agri-food imports

\begin{tabular}{|c|c|c|}
\hline $\begin{array}{c}\text { Non-agri-food importer } \\
\text { countries }\end{array}$ & $\begin{array}{c}\text { Processed food } \\
\text { importer countries }\end{array}$ & $\begin{array}{c}\text { Primary commodity } \\
\text { importer countries }\end{array}$ \\
\hline
\end{tabular}

\begin{tabular}{|c|c|c|}
\hline $\begin{array}{c}\text { Finland } \\
\text { Estonia } \\
\text { Latvia } \\
\text { Lithuania } \\
\text { Slovakia } \\
\text { Hungary } \\
\text { Slovenia } \\
\text { Croatia } \\
\text { Bulgaria } \\
\text { Cyprus } \\
\text { Malta } \\
\text { Luxembourg }\end{array}$ & $\begin{array}{c}\text { Sweden } \\
\text { Denmark } \\
\text { Ireland } \\
\text { Poland } \\
\text { Czech Republic } \\
\text { Austria }\end{array}$ & $\begin{array}{c}\text { Portugal } \\
\text { Romania } \\
\text { Greece }\end{array}$ \\
\hline $\begin{array}{l}\text { All commodities are } \\
\text { imported in the lowest } \\
\text { quantity and value } \\
\text { within the EU. }\end{array}$ & $\begin{array}{l}\text { Dairy products, meat } \\
\text { and meat preparations, } \\
\text { fresh milk, prepared } \\
\text { food, fruits and } \\
\text { vegetables are imported } \\
\text { in the largest quantity } \\
\text { and value within the } \\
\text { EU. }\end{array}$ & $\begin{array}{l}\text { Cereals, fresh milk, } \\
\text { oilseeds and sugar are } \\
\text { imported in the largest } \\
\text { quantity and value } \\
\text { within the EU. }\end{array}$ \\
\hline
\end{tabular}

\section{CONCLUSIONS}

The EU is one of the most open economies in the world. European goods and services account for 35\% of the EU's GDP. The EU manages foreign trade in millions of Euro per year. However, trade features of each Member State and their share in the EU's foreign trade is not uniform.

The year of the EU accession, agricultural subsidies, share of exports and imports by partner and by products and the export value of sugar, fruit and vegetables do not correlate with any of the other (examined) factors. This means that agricultural subsidies do not influence the agricultural foreign trade of the member states, so these have no trade-distorting effects. Furthermore, the date of EU accession does not make any difference from the point of view of the foreign trade of the member states. The countries that joined later are also not at a disadvantage.

It can be ascertained that the generally known fact that the national income (GDP and its components) have a strong positive correlation with agricultural production as well as with the total food exports and imports of a country (it was found that this is especially true with the imports of animal products). Thus, those countries that have a significant agricultural production, produce food commodities in larger quantities of which a large part are exported outside the EU.

It can be also proved that those member states that have significant extra-EU exports, import commodities in a higher quantity as well. The milk and dairy product exporters (i.e., significant dairy cow breeder countries such as Germany, France, Netherlands, Belgium, Italy, Denmark, Ireland, Poland, and the UK) are the main market for crop producers from other member states. However these countries are the largest member states, so their exports and imports are significant in regards to other commodities as well, so it does not necessarily mean that there is a logical correlation between these two variables. It can be supported also with the result that the largest meat exporter countries import mainly fruits and vegetables. However these biggest meat exporters are the same as the biggest dairy exporters. 
Prepared food exports and imports correlate strongly with each other. So if a country produces and exports prepared foods in a large quantity, it also imports these goods in a larger quantity.

There are member states that have similar trade features. These countries may make up different groups of member states. As for the food trade features, there are some countries (mainly Central-European countries) that do not export a significant quantity of food commodities outside the EU. On the contrary, there are countries that manage their food exports mainly extra-EU and others that are the main partners of the third countries. These last two ones are the Northern and Southern European countries, which have important ports. For the smallest EU member states the most important commercial goods are food commodities and there are some countries of which food exports are much higher than food imports. As for the structure of agri-food exports, there are typical non-agri food exporter countries (most of them joined the EU after the 2000s) and others are typical agrifood exporters (joined before the 2000s). Crop production and primary commodities are exported mainly by Central and Eastern European member states, while processed products are exported by the UK and Italy. As for the structure of agri-food imports, these can be classified into three groups of member states. Non-agri-food importer countries are almost the same countries as the non-agri-food exporter countries. The primary commodity importer member states are some Mediterranean countries, while processed food importers are the main agri-food exporters in addition to some of the primary commodity exporter countries.

\section{REFERENCES}

Beckman J., Arita S., Mitchell L., Burfisher M. (2015): Agriculture in the Transatlantic Trade and Investment Partnership: tariffs, tariffrate quotas, and non-tariff measures ER-198. Washington, DC: USDA Economic Research Service

Brülhart M., Matthews A. (2007): EU external trade policy forthcoming. In El-Agraa AM., editor. The European Union: economics \& policies. Cambridge: Cambridge University Press. http://www.hec.unil.ch/mbrulhar/papers/elagraa610.pdf. Approached May 2016.

Chever T., Renault C., Renault S., Romieu V. (2012): Value of production of agricultural products and foodstuffs, wines, aromatised wines and spirits protected by a geographical indication. Final Report. Brussels: European Commission/AND International

Bureau JC., Disdier AC., Emlinger C., Foure J., Felbermayr G., Fontaigne L., Jean S. (2014): Risks and opportunities for the EU agri-food sector in a possible EU-US trade agreement. Brussels: European Parliament Policy Department B: Structural and Cohesion Studies

DG Agriculture and Rural Development (2015): EU cereals trade: 2014/15 marketing year. Brussels: Committee for the Common Organisation of Agricultural Markets: Agri C 4. http://ec.europa. eu/agriculture/cereals/trade/cereals/2014-2015 en.pdf. Approached May 2016.

Eicher TS., Henn C. (2011): In Search of WTO Trade Effects:
Preferential Trade Agreements Promote Trade Strongly but Unevenly, Journal of International Economics 2011; 83(2): 137-153.

EPP (European People's Party) (2015): de Pablo, P. L. (Ed.) EPP Group Position Paper on International Trade. Brussels: European Parliament

www.eppgroup.eu\%2Fdocument\%2F97461\&usg=AFQjCNEHGl8 bnRwDXIPbfHNx2N4qptqptw\&sig2=Ajov63moEQ9s9rCCQWF Kwg\&cad=rja. Approached May 2016.

Mazure G., Tiltina S. (2015): Export-import dynamics within the European Union trade policy. Paper presented at the 2015 International Conference "Economic Science for Rural Development", Jelgava, 23-24 April 2015, 268-279.

IGC (International Grains Council) (2016): Grain Market Report 462: 21st January 2016. http://www.igc.int/downloads/gmrsummary/ gmrsumme.pdf. Approached May 2016 
